3. Жеребцов А. Н., Павлов Н. В. Административная правоприменительная практика: теоретический и практический аспекты. М.: ЮСТИЦИН-ФОРМ. 2018. С. 78.

4. Жеребцов А. Н., Павлов Н. В. Вопросы сущности и правоприменительного значения административной практики. // Lex Russica. 2019. № 3(148). С. 38.

5. Павлов Н. В., Бельчик А. М. Проблемы административной ответственности несовершеннолетних // Бюллетень науки и практики. 2019. Т. 5. №6. С. 402-406. https://doi.org/10.33619/2414-2948/43/53.

\title{
Сурайкина О.И. \\ Вопросы расторжения договора об оказании образовательных услуг со стороны исполнителя / заказчика
}

Российская государственная академия интеллектаульной собственности

(Россия, Москва)

doi: $10.18411 / \mathrm{j}-07-2021-102$

\section{Аннотация}

В статье рассматриваются вопросы расторжения договора об оказании образовательных услуг со стороны исполнителя / заказчика. Определены обязанности сторон (образовательного учреждения и обучающегося). Проанализированы основания и некоторые условия расторжения договора об оказании образовательных услуг со стороны исполнителя и заказчика. Сделан вывод о том, что вопросы расторжения договора об оказании образовательных услуг со стороны исполнителя / заказчика обусловлены спецификой самого договора: двусторонность выполнения обязанностей сторон, социальная значимость образования, необходимость соблюдения норм закона в рамках как договора о возмездном оказании услуг, так и договора об оказании образовательной услуги, основания для прекращения договорных отношений.

Ключевые слова: условия расторжения договора, договор об оказании образовательных услуг, исполнитель, заказчик.

\section{Abstract}

The article deals with the termination of an agreement on the provision of educational services by the contractor / customer. The responsibilities of the parties (educational institution and student) are defined. The grounds and some conditions for termination of the contract on the provision of educational services by the contractor and the customer have been analyzed. It was concluded that the issues of termination of the contract on the provision of educational services by the contractor / customer are due to the specifics of the contract itself: the two-sided performance of the obligations of the parties, the social significance of education, the need to comply with the law within the framework of both the contract for the provision of paid services and the contract for the provision educational services, grounds for termination of the contractual relationship.

Keywords: terms of termination of the contract, contract for the provision of educational services, contractor, customer.

К основным обязанностям образовательного учреждения по договору об оказании образовательных услуг относится обеспечение качественного образования.

Предоставление образовательной услуги характеризуется тем, что результат предполагает двусторонние действия заказчика (образовательного учреждения) и исполнителя (обучающегося). Образовательное учреждение обеспечивает получение знаний, а заказчик обязан присутствовать на занятиях, проходить аттестацию, сдавать зачеты и экзамены в установленные сроки, ликвидировать академическую задолженность.

Одной из особенностей договора об оказании образовательных услуг является возможность исполнителя и заказчика отказаться от его исполнения в одностороннем 
порядке согласно ст. 782 ГК РФ [3]. В большинстве случаев данной стороной является заказчик. Тем не менее М.А. Волкова отмечает, что разногласия между заказчиком и исполнителем договора об оказании образовательных услуг в случае отказа от его исполнения обусловлены неопределенностью момента заявления отказа, сумм, подлежащих возврату по договору. Данное обстоятельство можно объяснить отсутствием разъяснений высших судебных инстанций [2].

Анализ нормы п. 1 ст. 782 ГК РФ [3], согласно которой заказчик имеет право отказаться от исполнения договора при условии оплаты исполнителю фактически понесенных расходов, позволяет определить следующие условия расторжения договора об оказании образовательных услуг:

- односторонний отказ от исполнения договора ввиду отсутствия необходимости его согласования с исполнителем или обращения в суд с требованием о его расторжении;

- отказ от исполнения договора об оказании образовательных услуг в ситуациях, когда договор заключен между образовательным учреждением и работодателем, направившим на обучение своих работников. В данном случае данный договор следует рассматривать как договор в пользу третьих лиц. Соответственно, при желании заказчика отказаться от исполнения договора об оказании образовательных услуг верным будет получить согласие работника о расторжении договора. Следует отметить, что образовательные учреждения в большинстве случаев пренебрегают данной нормой. В результате может возникнуть ситуация, когда работник заказчика продолжает пользоваться образовательной услугой, хотя заказчик направил исполнителю уведомление об отказе от исполнения договора. В данном случае заказчик обязан оплатить услуги за пользование образовательной услугой работником.

Закрепление права на односторонний отказ от исполнения договора об оказании услуг в ГК РФ не предусматривает основания для заявления отказа. Соответственно, расторжение договора об оказании образовательных услуг со стороны заказчика возможно по основаниям:

— желание обучаться в другом образовательном учреждении;

- отсутствие необходимости / нежелание дальнейшего обучения;

- нарушение исполнителем своих обязательств по договору и т.д.

В связи с этим отказ от исполнения договора об оказании образовательных услуг со стороны заказчика возможен как по определенным основаниям, так и при нарушении условий договора (ст. ст. 450, 328, 405 ГК РФ) [3]. В первом случае заказчик должен оплатить все понесенные исполнителем расходы. Во втором случае, если заказчик отказывается оплачивать исполнителю понесенные им расходы, то ему необходимо доказать факт нарушения и его существенность.

Иным образом представлена судебная практика по расторжению договора об оказании образовательных услуг со стороны исполнителя (образовательного учреждения).

Следует различать односторонний отказ от исполнения договора об оказании образовательных услуг и отказ ввиду невозможности его исполнять по вине заказчика (п. 2 ст. 781 ГК РФ) [3]. В последнем случае услуги подлежат оплате в полном объеме, если иное не предусмотрено законом или договором возмездного оказания услуг.

В качестве примера можно привести дело гражданина Б., который приказом ректора был зачислен на очное обучение на условиях оплаты. На втором курсе обучающийся был отчислен из ВУЗа приказом ректора с формулировкой «в связи с невозможностью исполнения обязательств университета по вине обучающегося» ввиду 
систематических пропусков занятий. ВУЗ отказался возвратить не израсходованные денежные средства ввиду наличия запланированных расходов на обеспечение образовательного процесса.

При разрешении разногласий между сторонами суды первой и второй инстанции исходили из нормы 39 ГК РФ (п. 2 ст. 781 ГК РФ) [3], согласно которой ВУЗ не должен возмещать сумму платы за обучение при досрочном расторжении договора ввиду неисполнения заказчиком своих обязанностей. Данное решение поддержала судебная коллегия [5]. Таким образом, целесообразно считать, что в качестве основания для одностороннего отказа от исполнения договора не может выступать невозможность его исполнения по вине заказчика.

Существенным нарушением условий договора со стороны исполнителя следует назвать предоставление некачественно образования или предоставление образовательной услуги с нарушениями.

Ориентируясь на Примерную форму договора об оказании образовательных услуг государственными и муниципальными общеобразовательными учреждениями, утвержденной Приказом Минобразования РФ от 10 июля 2003 г. N 2994 [6], следует отметить следующие основания для расторжения договора со стороны образовательного учреждения:

- систематическое нарушение обучающимся прав и законных интересов других обучающихся и работников исполнителя, расписания занятий (например, неявка на занятия);

- препятствование нормальному осуществлению образовательного процесса (например, нарушение дисциплины).

В случае подобных нарушений исполнитель вправе отказаться от договора, если после ее предупреждений потребитель не устранит нарушения. Более того, согласно п. 9 ст. 16 Закона о высшем и послевузовском профессиональном образовании, за нарушение обязанностей, предусмотренных уставом высшего учебного заведения, к обучающемуся могут быть применены дисциплинарные взыскания вплоть до отчисления из ВУЗа [1].

Согласно С.П. Гришаеву, одним из условий расторжения договора об оказании образовательных услуг является оформление отказа от его исполнения: руководствуясь нормой ст. 452 ГК РФ, соглашение о расторжении договора должно быть совершено в той же форме, что и сам договор - в письменной [4]. Следует отметить, что прекращение договора возможно в любой период времени до истечения срока его исполнения. При этом установление в договоре каких-либо сроков уведомления об отказе от исполнения договора (например, не позднее, чем за 10 дней до предполагаемой даты расторжения договора), а также ограничений, допускающих отказ по истечении определенного срока действия договора, является неправомерным.

Одним из оснований расторжения договора является академическая неуспеваемость обучающегося. Суды признают право образовательного учреждения на отказ от исполнения договора в одностороннем порядке, руководствуясь ст. 310 ГК РФ и п. 2 ст. 782 ГК РФ [7].

Однако норма п. 2 ст. 782 ГК РФ [3] указывает на право исполнителя отказать от исполнения договора лишь при условии полного возмещения заказчику убытков, что противоречит фактическому основанию для его прекращения - заказчик (обучающийся) нарушил условие договора о необходимости выполнения учебного плана. Тем не менее данную норму все же можно применить к договору об оказании образовательных услуг в случае, если в нем на уровне закона предусмотрены и точно определены основания отказа от договора по инициативе образовательного учреждения, что объясняется социальной значимостью образования. Ввиду данной ситуации В.В. Кванина предложила рассматривать п.2. 782 ГК РФ рассматривать в новой редакции: «Исполнитель вправе отказаться от исполнения обязательств по 
договору возмездного оказания услуг, если иное не предусмотрено законом, лишь при условии полного возмещения заказчику убытков» [4].

В практике образовательных учреждений в договоре часто можно встретить право исполнителя в одностороннем порядке расторгнуть договор в случае неоплаты, просрочки оплаты образовательных услуг обучающимся. Подобные формулировки условий являются нарушениями ввиду несоответствия нормам ст. 310 ГК РФ, согласно которой отказ от исполнения обязательства и одностороннее изменение его условий допускаются только в случаях, когда это специально предусмотрено законом. Следовательно, подобные условия договора являются неправомерными. Руководствуясь п. 2 ст. 782 ГК РФ [3], в которой закреплено право исполнителя на отказ от исполнения договора при условии полного возмещения заказчику убытков, следует отметить, что включение в договор пункта об одностороннем прекращении действия договора об оказании образовательных услуг в случаях неоплаты, просрочки оплаты со стороны обучающегося, а также его отчисления за неуспеваемость является незаконным.

Таким образом, на основании вышеизложенного целесообразно сделать вывод о том, что вопросы расторжения договора об оказании образовательных услуг со стороны исполнителя / заказчика обусловлены спецификой самого договора: двусторонность выполнения обязанностей сторон, социальная значимость образования, необходимость соблюдения норм закона в рамках как договора об возмездном оказании услуг, так и договора об оказании образовательной услуги, основания для прекращения договорных отношений.

$$
* * *
$$

1. Волегова Ю. С. Некоторые особенности правоотношений, возникающих из договора на оказание образовательных услуг / Ю. С. Волегова // Молодой ученый. - 2015. - № 23 (103). - С. 739-741.

2. Волкова М.А. Эффективность формирования системы права в современных условиях / М.А. Волкова // История государства и права. - 2013. - № 16. - С. 30-32.

3. Гражданский кодекс Российской Федерации (ГК РФ) [Электронный ресурс] // КонсультантПлюс http://www.consultant.ru/ (дата обращения: 05.06.2021).

4. Гриднева О.В. Особенности защиты прав потребителей образовательных услуг / О.В. Гриднева // Nauka-Rastudent.ru. - 2015. - № 7 (19). - C.38-42.

5. Определение судебной коллегии по гражданским делам Санкт-Петербургского городского суда от 12.08.2014 по делу № 33-10823 /2014 // Официальный сайт Санкт-Петербургского городского суда. Судебные акты// СПС «КонсультантПлюс. Судебная практика»

6. Приказ Минобрнауки России от 13.01.2014 № 8 «Об утверждении примерной формы договора об образовании по образовательным программам дошкольного образования» // Российская газета. № 83.- 2014.

7. Стародумова С.Ю. О соотношении мер защиты и мер ответственности в гражданском праве / С.Ю, Стародумова // Основные проблемы и тенденции развития в современной юриспруденции. Сборник научных трудов по итогам международной научно-практической конференции. Волгоград, 2015. - С. 40-42.

\section{Тетерина C.B.}

Установление возраста уголовной ответственности и наказаний несовершеннолетних в дореволюционном уголовном праве России

Курский государственный университет (Россия, Курск)

doi: $10.18411 / \mathrm{lj}-07-2021-103$

Научньй руководитель Афанасьев А.Н.

\section{Аннотация}

В статье рассматривается становление и развитие института уголовной ответственности несовершеннолетних в дореволюционной России, отмечается общая 